CLINICAL STUDY

\title{
The comparison of serum vascular endothelial growth factor levels between patients with metastatic and non-metastatic thyroid cancer, and patients with nontoxic multinodular goiter
}

\author{
Joanna Klubo-Gwiezdzinska ${ }^{1}$, Roman Junik ${ }^{1}$, Ewa Kopczynska ${ }^{2}$, Olga Juraniec ${ }^{1}$ and Hanna Kardymowicz ${ }^{3}$ \\ Departments of ${ }^{1}$ Endocrinology and Diabetology and ${ }^{2}$ Pathobiochemistry and Clinical Biochemistry, Collegium Medicum in Bydgoszcz, Nicolaus \\ Copernicus University in Torun, ul. M. Sklodowskiej-Curie 9, 85-094 Bydgoszcz, Poland and ${ }^{3}$ Department of Laboratory Diagnostics, Oncology Centre in \\ Bydgoszcz, ul. dr I.Romanowskiej 2, 85-796 Bydgoszcz, Poland \\ (Correspondence should be addressed to J Klubo-Gwiezdzinska who is now at Klinika Endokrynologii i Diabetologii, Szpitala Uniwersyteckiego im. A. Jurasza \\ w Bydgoszczy, ul. M. Sklodowskiej-Curie 9, 85-094 Bydgoszcz, Poland; Email: adamgw@poczta.onet.pl)
}

\begin{abstract}
Background: One of the important proangiogenic factors involved in the growth of normal and neoplastic tissues is vascular endothelial growth factor (VEGF).

Aim: We hypothesized that serum VEGF concentration would differ between patients with metastatic and non-metastatic thyroid cancer, multinodular goiter, and healthy subjects. We also hypothesized that endogenous TSH stimulation would affect serum VEGF level.

Subjects and methods: The study group consisted of 71 patients (62 females and 9 males), aged $44.9 \pm$ 12.3 years, with differentiated thyroid cancer (50 papillary, 17 follicular, and 4 oxyphilic), treated in our department during the years 2003-2006. All patients had undergone total or near-total thyroidectomy and radioactive iodine treatment, that had resulted in remission in 59 patients and persistent/recurrent disease in 12 patients. The study included two control groups: 30 patients with nontoxic multinodular goiter and 30 healthy subjects.

Results: Serum VEGF concentrations were significantly higher in patients with distant metastases than those in remission or healthy patients. (423.4 vs 217.6 vs $235.55 \mathrm{pg} / \mathrm{ml}$ respectively, $P<0.05$ ). This was not observed in patients with locoregional metastases. During endogenous TSH stimulation, VEGF decreased significantly (215.3 vs $169.6 \mathrm{pg} / \mathrm{ml}, P<0.05)$. Patients with multinodular goiter showed significantly lower VEGF concentrations than the remaining study groups.

Conclusions: Serum VEGF concentration might be used as an additional marker of thyroid cancer with distant metastases, but its interpretation should be undertaken very cautiously. Endogenous TSH stimulation decreases VEGF levels in patients either with or without thyroid tissue, suggesting that its regulatory effects are through receptors located outside the thyrocytes.
\end{abstract}

European Journal of Endocrinology 157 521-527

\section{Introduction}

Angiogenesis is an important process involved in the growth of normal and neoplastic tissues. Among known promoters of angiogenesis is the vascular endothelial growth factor (VEGF), the glycoprotein synthesized by the gene located on the $6 \mathrm{p} 21.3$ chromosome $(1,2)$. VEGF is expressed in normal thyroid as well as in thyroid pathologies such as Graves' disease, thyroiditis, and thyroid cancer (3-5). There is evidence that VEGF concentration is directly related to the neovascularization of the thyroid gland (6).

Numerous studies have shown higher VEGF expression in thyroid cancer tissues than in benign thyroid nodules and normal thyroid tissues (7-12).

Some authors have suggested using high VEGF tissue expression as a prognostic factor for locoregional or distant recurrence or poor prognosis $(7,8,10,11$, $13,14)$.
The measurement of VEGF tissue expression demands complicated immunohistochemical procedures. A more useful tool for clinicians is the estimation of serum VEGF levels. There are few studies of serum VEGF levels in patients suffering from thyroid cancer $(15,16)$. There are no data comparing serum VEGF levels of patients suffering from multinodular goiter to healthy subjects.

Very few studies describe the effect of recombinant human thyroid-stimulating hormone (rhTSH) stimulation on VEGF production by thyroid cancer cells. The results of in vitro studies are contradictory to those in vivo (15-19). There is no data relating to the effect of endogenous TSH stimulation on VEGF production.

Therefore, we conducted a study aimed at investigating four hypotheses: first, whether serum VEGF concentrations are elevated in metastatic thyroid cancer; secondly, whether serum VEGF concentration 
in patients with remission is similar to the healthy subjects; thirdly, if endogenous TSH stimulation results in a change in serum VEGF concentration in patients with differentiated thyroid cancer; and finally if serum VEGF concentrations of patients with multinodular goiter differs from patients with thyroid cancer and healthy subjects.

\section{Materials and methods}

The study protocol was approved by the Ethical Committee of the Collegium Medicum in Bydgoszcz, Nicolaus Copernicus University in Torun, Poland. All patients gave informed consent.

The study included 91 patients treated in the Department of Endocrinology and Diabetology in Bydgoszcz, Nicolaus Copernicus University in Torun and the centre for Oncology in Bydgoszcz, during the years 2003-2006.

The inclusion criteria for the study were as follows: a well-differentiated thyroid cancer, diagnosed by an experienced histopathologist after total or near total thyroidectomy; radioactive iodine ablation; no evidence of remnant tissue in the thyroid bed uptake; no other known malignancies; normal platelet count.

From this group, we excluded 20 patients suffering from diabetes mellitus, hypertension, or heart failure because of their potential effect on the VEGF serum concentration (20).

The acquired group of 71 patients underwent a standard follow-up procedure: first, diagnostic whole body scintigraphy (WBS), thyroglobulin (Tg), anti-Tg antibodies and ultrasonography (USG) of the neck after endogenous TSH stimulation ( $\mathrm{TSH}>30 \mu \mathrm{IU} / \mathrm{ml}), 7-8$ months after ${ }^{131}$ I treatment; secondly, the frequency of the same procedure: in the case of full remission, after 2 years, then every 5 years; in patients with persistent/recurrent disease, 7-8 months after the additional treatment with radioiodine; and in the case of high-risk patients, every year; thirdly, systematic physical examination, TSH, and Tg measurements every 6 months during TSH suppression $(\mathrm{TSH}<0.05 \mu \mathrm{IU} / \mathrm{ml})$.

Full remission was defined as follows: Tg levels during $\mathrm{TSH}$ stimulation $<2 \mathrm{ng} / \mathrm{ml}$, or spontaneous fall of stimulated Tg below this level, during control provided after endogenous stimulation; absence of anti-Tg antibodies; negative WBS with 24-h uptake <0.1\%; normal results of the standard imaging procedures: USG of the neck, X-ray of the chest, or other (computed tomography, MRI, and PET, if needed).

The study included two control groups of 30 patients each.

The inclusion criteria for the first control group (healthy subjects) were: normal USG of the neck; TSH and platelet count within normal range; no evidence of chronic or acute diseases.
The inclusion criteria for the second control group (patients with nontoxic multinodular goiter) were: nodular goiter confirmed by exact cytologic analysis after fine needle aspiration cytology (FNAC); TSH and platelet count within normal range; no evidence of chronic or acute diseases. The exclusion criteria for the second group were: rapid increase in size of the nodule, firm consistency, irregularity, adhesion to soft tissues, or neck lymphadenopathy. Patients with nontoxic multinodular goiter were not treated with L-thyroxine (L-T4) or iodine.

In all groups, we measured VEGF serum concentrations.

\section{Serum samples}

Blood samples were obtained as a part of routine clinical evaluations (TSH, Tg, anti-Tg antibodies, and blood morphology). They were centrifuged for $15 \mathrm{~min}$ at $2500 \boldsymbol{g}, 30 \mathrm{~min}$ after donation. Serum was removed immediately and stored at $<-20{ }^{\circ} \mathrm{C}$ for $1-4$ months.

\section{Serum VEGF measurements}

Serum VEGF measurements were performed in batches using the Quantikine Human VEGF sandwich enzyme immunoassay technique (R\&D Systems, Minneapolis, MN, USA).

The intra-assay precision, expressed as coefficients of variation, was 4.5-6.7\%; the inter-assay precision $-6.2-8.8 \%$; and the sensitivity $<5 \mathrm{ng} / \mathrm{ml}$. All assays were performed in duplicate.

\section{Serum Tg measurements}

Serum Tg was measured with an IRMA assay (LIAISON, DiaSorin, Saluggia, Italy). The detection limit was $<0.2 \mathrm{ng} / \mathrm{ml}$. Reference values assuming patients with an intact thyroid were $0.2-70 \mathrm{ng} / \mathrm{ml}$.

\section{Serum anti-Tg antibodies measurements}

Serum anti-Tg antibodies were measured with an IRMA assay (LIAISON, DiaSorin). Detection limit was $<5 \mathrm{IU} / \mathrm{ml}$. Reference values were 5-100 IU/ml.

\section{Serum TSH measurements}

Serum TSH was measured with an ultrasensitive CMIA assay (ARCHITECT YOU 8200, Abbott Laboratories). Detection limit was $<0.0025 \mu \mathrm{IU} / \mathrm{ml}$. Reference values were $0.35-4.94 \mu \mathrm{IU} / \mathrm{ml}$.

\section{USG and FNAC}

The USG of the neck was performed by an ultrasonic probe of $7.5 \mathrm{MHz}$. The volume of the thyroid was 
Table 1 The results of the treatment in the study group.

\begin{tabular}{|c|c|c|c|c|c|}
\hline Group & $n$ & Proportion (\%) & Subgroup & $n$ & Proportion (\%) \\
\hline Remission & 59 & 83.1 & $\begin{array}{l}\text { Remission after the first dose of }{ }^{131} \text { I } \\
\text { Remission after the second dose of }{ }^{131} \text { I } \\
\text { Remission after the third dose of }{ }^{131} \mid \\
\text { Remission after the fourth dose of }{ }^{131} \text { I }\end{array}$ & $\begin{array}{r}41 \\
12 \\
5 \\
1\end{array}$ & $\begin{array}{c}57.8 \\
16.9 \\
7 \\
1.4\end{array}$ \\
\hline Metastases & 12 & 16.9 & $\begin{array}{l}\text { Distant metastases } \\
\text { Locoregional metastases }\end{array}$ & $\begin{array}{l}5 \\
7\end{array}$ & $\begin{array}{l}7 \\
9.9\end{array}$ \\
\hline
\end{tabular}

obtained using the following formula: (21)

$\mathrm{V}\left(\mathrm{cm}^{3}\right)=\mathrm{a}(\mathrm{cm}) \times \mathrm{b}(\mathrm{cm}) \times \mathrm{c}(\mathrm{cm}) \times 0.5$

where $V$ is the thyroid volume and $a, b$, and $c$ are thyroid dimensions.

FNAC was performed under USG control by an experienced cytologist. The biopsy was taken from the nodules $>1 \mathrm{~cm}$, and/or solid, hypoechogenic, with microcalcifications, without peripheral halo.

\section{Statistical analysis}

Normally distributed data are presented as mean \pm s.D., and not-normally distributed data are given as median. For normally distributed data, the Student $t$-test was used. Non-parametric tests were used when the data were not normally distributed. The groups were compared using Mann-Whitney's U test or ANOVA Kruskal-Wallis' test. Relationships among variables were sought using Spearman's correlation coefficient. Paired data were analyzed using Wilcoxon's test. Statistical significance was assumed when $P$ value was $\leq 0.05$.

\section{Results}

Baseline serum samples were obtained from 71 patients (62 women and 9 men). The mean age at the time of the study was $44.9 \pm 12.3$ years and the mean duration of the disease was $53.3 \pm 45.8$ months. Paired samples (during suppression and after endogenous TSH stimulation) were available from 40 patients, according to follow-up procedures during 2003-2006. Two control groups, each consisting of 30 patients, were comparable according to age and sex with the study group.

Histological classification revealed 50 (70.4\%) papillary thyroid cancers, 17 (24\%) follicular thyroid cancers, and 4 (5.6\%) oxyphilic thyroid cancers.

Among the group, $59(83.1 \%)$ patients reached the remission criteria. The remaining 12 (16.9\%) patients showed biochemical and morphological evidence of metastatic disease (Table 1).

Serum VEGF measures were not dependent on age, sex, histological type of cancer, duration of disease, number of radioiodine doses, or the total dose of ${ }^{131} \mathrm{I}$ used in the treatment.
Concentrations of VEGF in each group are presented in Table 2 .

The serum VEGF concentration was significantly higher in patients with distant metastases of the thyroid cancer, in comparison with cured patients and healthy subjects $(P<0.05$; Fig. 1$)$. Localization of distant metastases and serum VEGF, Tg, and TSH levels during suppression and stimulation are presented in Table 3.

Serum VEGF concentration in patients with locoregional metastases did not differ significantly from patients in remission or healthy persons (Fig. 1). Localization of locoregional metastases and serum VEGF, Tg, and TSH levels during suppression and stimulation are presented in Table 4.

Patients with remission had VEGF concentrations comparable to healthy subjects (Fig. 1).

Patients with nontoxic nodular goiter showed significantly lower VEGF concentrations than the healthy controls $(P<0.01$; Fig. 2$)$ and other groups $(P<0.05)$.

In both control groups (patients with nodular goiter and healthy controls), there was no relationship between VEGF concentration and thyroid volume. Additionally, patients with nodular goiter presented no correlation between VEGF and the number of nodules.

During endogenous TSH stimulation, in 40 patients with thyroid cancer, VEGF significantly decreased (Fig. 3). This was observed in metastatic as well as non-metastatic patients. There was no correlation between VEGF and Tg during suppression and stimulation, in patients with metastatic disease. The VEGF level was not dependent on the number of metastatic foci.

Table 2 Serum vascular endothelial growth factor (VEGF) concentration in each study group.

\begin{tabular}{lrrrr}
\hline VEGF $(\mathrm{pg} / \mathrm{ml})$ & $\boldsymbol{n}$ & Mean & s.D. \pm & Median \\
\hline Remission suppression & 59 & 285.4 & 208.5 & 217.6 \\
$\begin{array}{l}\text { Locoregional metastases } \\
\quad \text { suppression }\end{array}$ & 7 & 289.9 & 184.2 & 258.3 \\
$\begin{array}{l}\text { Distant metastases } \\
\quad \text { suppression }\end{array}$ & 5 & 589.2 & 474.3 & 423.4 \\
$\begin{array}{l}\text { Nodular goiter } \\
\text { Healthy }\end{array}$ & 30 & 162.2 & 193.3 & 103.0 \\
\hline
\end{tabular}




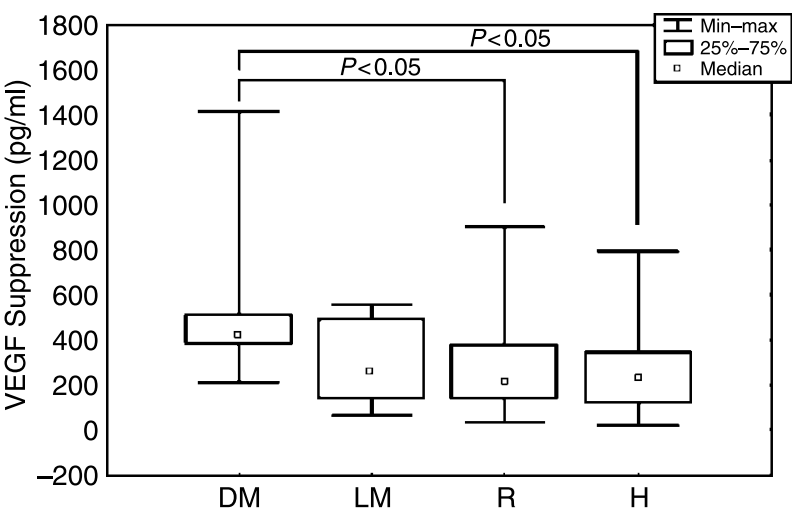

Figure 1 Differences in the serum VEGF concentration between patients with thyroid cancer and healthy subjects. DM, patients with distant metastases; LM, patients with locoregional metastases; R, patients with remission; $\mathrm{H}$, healthy subjects.

\section{Discussion}

This study demonstrates that patients with distant metastases have significantly higher serum VEGF levels than patients in remission. However, patients with only locoregional metastases did not demonstrate increased VEGF levels when compared with patients in remission. As expected, VEGF concentrations did not differ between patients in remission and healthy controls.

There are two previous studies with a similar aims to ours. Tuttle et al. demonstrated significantly increased serum VEGF level in patients with metastatic thyroid cancer in comparison with patients in remission. The observation related to thyroid cancer with distant metastases, which was similar to our results, as well as thyroid cancer with locoregional metastases, which was not confirmed by this study. Sorvillo et al. also showed increased serum VEGF levels in patients with metastases, but they did not analyze the effect of the location of metastases $(15,16)$.

There are two possible reasons for the discrepant results referring to the patients with locoregional metastases: Firstly the proportion of patients with locoregional metastases might have influenced the statistical analysis: in our study, it was $10 \%$ ( $n=7$ out of 71$)$; in Tuttle's, it was $24 \%(n=15$ out of 63$)$; and in Sorvillo's, the metastases were not divided to locoregional and distant, but they were observed in $40 \%$ of patients $(n=18$ out of 45$)$.

Differences in exclusion criteria are the other possible reason. In our study, patients with hypertension, diabetes, heart failure, abnormal platelet count, and known malignancies other than thyroid cancer were excluded because of their potential effect on the VEGF level $(2,20)$. The authors of the studies presented above described 'other known malignancies and abnormal platelet count' as exclusion criteria.

All studies have confirmed similar VEGF levels in patients in remission and healthy subjects.

In addition, histopathological studies are not univocal regarding VEGF expression in thyroid cancer tissues with locoregional metastases $(7-10,22)$ Several studies, similarly to our observations, did not demonstrate elevated VEGF expression in thyroid cancers with locoregional metastases. Interestingly, in these cases, specific isoforms of VEGF (VEGF-C and VEGF-D), responsible for lymphangiogenesis, were increased (23-25).

The assessment of serum VEGF-C and VEGF-D was not the aim of our study, but this is worth further research because it might be an explanation for the discrepancies between the presented results.

The clinical usefulness of serum VEGF level has some limitations: there are overlapping data between all the observed subgroups. This refers mainly to the interpretation of low VEGF levels - in some cases, they are observed even in patients with distant metastases (Table 3).

Since serum VEGF level does not correlate with the Tg level and the number of metastatic foci, it cannot be used as a marker of the extension of persistent/recurrent disease.

VEGF might be used as an additional marker in patients with a thyroid cancer resistant to the standard treatment. High VEGF concentrations in these patients may be a target of a novel treatment with anti-VEGF antibodies or VEGF receptor inhibitors (26-29).

Table 3 Serum vascular endothelial growth factor (VEGF), Tg, and thyroid-stimulating hormone (TSH) levels during suppression and stimulation in patients with distant metastases.

\begin{tabular}{|c|c|c|c|c|c|c|c|c|}
\hline & $\begin{array}{l}\text { TNM staging } \\
\text { at the } \\
\text { diagnosis }\end{array}$ & $\begin{array}{l}\text { Localization of } \\
\text { metastases }\end{array}$ & $\begin{array}{c}\text { VEGF } \\
\text { suppression } \\
(\mathrm{pg} / \mathrm{ml})\end{array}$ & $\begin{array}{c}\text { VEGF } \\
\text { stimulation } \\
(\mathrm{pg} / \mathrm{ml})\end{array}$ & $\begin{array}{c}\text { Tg } \\
\text { suppression } \\
(\mathrm{ng} / \mathrm{ml})\end{array}$ & $\begin{array}{c}\mathrm{Tg} \\
\text { stimulation } \\
(\mathrm{ng} / \mathrm{ml})\end{array}$ & $\begin{array}{c}\text { TSH } \\
\text { suppression } \\
(\mu \mathrm{IU} / \mathrm{ml})\end{array}$ & $\begin{array}{c}\text { TSH } \\
\text { stimulation } \\
(\mu \mathrm{l} U / \mathrm{ml})\end{array}$ \\
\hline 1 & Follicular IV & Bones $->20$ foci & 379.2 & 502.5 & 10.8 & 228.4 & 0.063 & 38.236 \\
\hline 2 & Papillary II & $\begin{array}{l}\text { Non-iodine absorbing: } \\
\text { mediastinum - } 3 \\
\text { foci; thyroid bed - } 1 \\
\text { focus }\end{array}$ & 1414.6 & & 13.6 & & 0.015 & \\
\hline 3 & Papillary III & Lungs - 9 foci & 515.9 & 259.7 & Anti-Tg (+) & Anti-Tg (+) & 0.013 & 68.300 \\
\hline 4 & Follicular II & $\begin{array}{l}\text { Lungs }-4 \text { foci, thyroid } \\
\text { bed }-1 \text { focus } 4 \mathrm{~cm}\end{array}$ & 423.4 & 246.6 & 12.8 & 56.7 & 0.002 & 35.500 \\
\hline 5 & Papillary II & Lungs - 12 foci & 212.7 & 82.3 & 4.9 & 16.8 & 0.025 & 44.800 \\
\hline
\end{tabular}


Table 4 Serum vascular endothelial growth factor (VEGF), Tg, and thyroid-stimulating hormone (TSH) levels during suppression and stimulation in patients with locoregional metastases.

\begin{tabular}{|c|c|c|c|c|c|c|c|c|}
\hline & $\begin{array}{l}\text { TNM staging } \\
\text { at the } \\
\text { diagnosis }\end{array}$ & $\begin{array}{l}\text { Localization of } \\
\text { metastases }\end{array}$ & $\begin{array}{l}\text { VEGF sup- } \\
\text { pression } \\
(\mathrm{pg} / \mathrm{ml})\end{array}$ & $\begin{array}{c}\text { VEGF } \\
\text { stimulation } \\
(\mathrm{pg} / \mathrm{ml})\end{array}$ & $\begin{array}{c}\text { Tg } \\
\text { suppression } \\
(\mathrm{ng} / \mathrm{ml})\end{array}$ & $\begin{array}{c}\mathbf{T g} \\
\text { stimulation } \\
(\mathrm{ng} / \mathrm{ml})\end{array}$ & $\begin{array}{l}\text { TSH sup- } \\
\text { pression } \\
(\mu \mathrm{lU} / \mathrm{ml})\end{array}$ & $\begin{array}{c}\text { TSH } \\
\text { stimulation } \\
(\mu \mathrm{IU} / \mathrm{ml})\end{array}$ \\
\hline 1 & Papillary III & Cervical lymph nodes - 8 foci & 493.8 & 413.7 & 3.78 & 37.29 & 0.007 & 31.000 \\
\hline 2 & Follicular II & Cervical lymp & & & 2.2 & 10.2 & & \\
\hline 3 & Papillary II & Cervical lymph nodes - 2 foci & 258.3 & 234.8 & 2.56 & 4.22 & 0.005 & 60.889 \\
\hline 4 & Oxyphilic II & Cervical lymph nodes -1 focus & 559.6 & 42.6 & 2.4 & 4.9 & 0.025 & 30.800 \\
\hline 5 & Papillary II & Cervical lymph nodes -1 focus & 65.3 & 76.8 & 58.15 & 60.32 & 0.025 & 38.499 \\
\hline 6 & Papillary II & Cervical lymph nodes -1 focus & 138.8 & & Anti-Tg $(+)$ & Anti-Tg $(+)$ & 0.025 & \\
\hline 7 & Follicular II & Cervical lymph nodes -2 foci & 176.8 & 158.7 & 4.5 & 10.22 & 0.005 & 62.976 \\
\hline
\end{tabular}

We observed a significant decrease in serum VEGF levels after endogenous TSH stimulation in patients with metastatic disease and remission. According to our knowledge, the influence of endogenous stimulation on VEGF levels is described here for the first time. The studies of Tuttle et al. and Sorvillo et al. were focused on an exogenous rhTSH stimulation and have shown different results - stable VEGF level after stimulation (15) or time-dependent significant decrease (16).

We observed a significant decrease in VEGF levels, even in patients in remission, i.e. those without clinical or biochemical evidence of disease. These observations suggest that TSH regulates VEGF synthesis through receptors not exclusively located in follicular thyroid cells. The expression of TSH-receptors in tissues other than the thyroid gland was confirmed by Sorisky et al. (30).

Some of the in vitro studies are in agreement with ours, showing that TSH down-regulates the VEGF production by thyroid cells grown in culture $(31,32)$. However, other results did not confirm this observation $(17,33,34)$.

The other possible reason for the decrease of VEGF levels in both groups (patients with and without remission) is hypothyreosis after withdrawal of L-T4, interpreted as an additional disease which might have influenced the VEGF level.

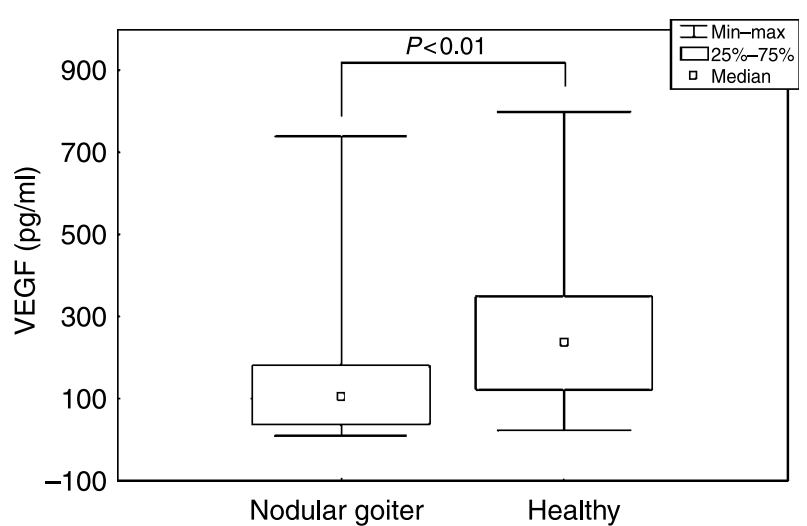

Figure 2 Differences in the serum VEGF concentrations between patients with nodular goiter and healthy subjects.
We observed significantly lower VEGF levels in patients with multinodular goiter in comparison with the patients with thyroid cancer and the healthy ones.

The observation that VEGF levels are lower in patients with benign nodules when compared to the patients with active malignant neoplastic disease was not surprising. Several studies have documented similar observations $(7,11,12)$.

What was surprising was that our study documented lower serum VEGF levels in patients with multinodular goiter than in healthy ones. Again, to the best of our knowledge, this is the first report on this theme.

We can exclude potential inhibition of VEGF synthesis by iodine, which has been documented by an in vitro study in cultured human thyroid follicles (19). None of the patients with multinodular goiter received iodine or iodine-containing $\mathrm{L}-\mathrm{T} 4$.

A possible reason might be the crinopexy phenomenon, described by Gerard et al. They observed the trapping of VEGF in association with the extracellular matrix of goitrous thyroid, while the normal thyroid tissue expressed VEGF in epithelial cells (35).

This trapping might be an explanation for the decreased serum VEGF levels in patients with multinodular goiter observed in our study.

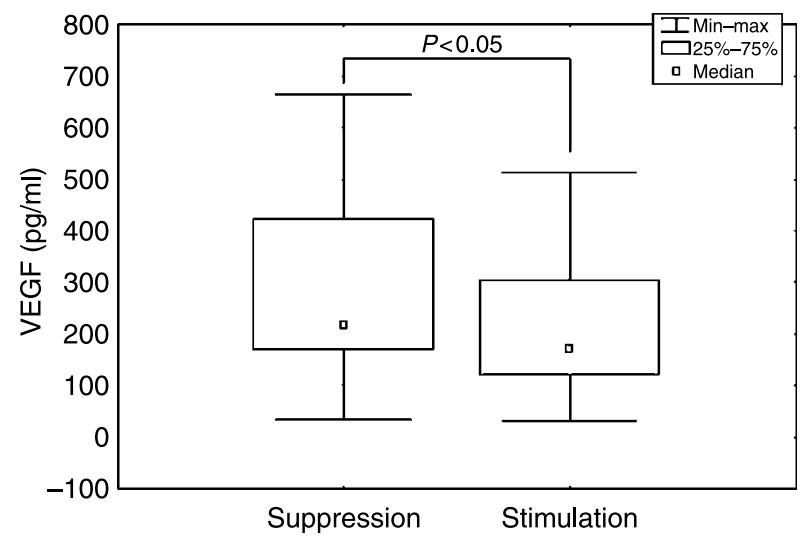

Figure 3 Differences in the VEGF concentrations in paired samples obtained during TSH suppression and stimulation. 


\section{Conclusions}

Mean serum VEGF levels are higher in patients with distant metastases of thyroid cancer than in patients with remission; patients in remission have the same VEGF levels as healthy subjects; endogenous TSH stimulation decreases VEGF levels in patients either with or without thyroid cells, suggesting regulatory effects through receptors located outside the thyroid gland; serum VEGF levels are not dependent on age, sex, histological type of cancer, duration of disease, number of radioiodine doses, or the total dose of ${ }^{131}$ I used in the treatment; serum VEGF concentrations in patients with multinodular goiter are lower than in healthy subjects.

\section{Funding}

Collegium Medicum Scientific Grant SD/51/03.

\section{References}

1 Ramsden JD. Angiogenesis in the thyroid gland. Journal of Endocrinology $2000 \mathbf{1 6 6} 475-480$.

2 Turner HE, Harris AL, Melmed S \& Wass JAH. Angiogenesis in endocrine tumors. Endocrine Reviews 200324 600-632.

3 Hedayati M, Kołomecki K, Pasieka Z, Korzeniowska M \& Kuzdak K. Serum levels of vascular endothelial growth factor and its receptors (sVEGFR-1, sVEGFR-2) in patients with benign and malignant thyroid tumors. Polish Journal of Endocrinology $200556253-258$.

4 Joory KD, Levick JR, Mortimer PS \& Bates DO. Vascular endothelial growth factor-C (VEGF-C) expression in normal human tissues. Lymphatic Research and Biology 20064 73-82.

5 Patel VA, Logan A, Watkinson JC, Uz-Zaman S, Sheppard MC, Ramsden JD \& Eggo MC. Isolation and characterization of human thyroid endothelial cells. American Journal of Physiology $2002 \mathbf{2 8 4}$ $168-176$.

6 Nagura S, Katoh R, Miyagi E, Shibuya M \& Kawaoi A. Expression of vascular endothelial growth factor (VEGF) and VEGF receptor 1 (Flt-1) in Graves disease possibly correlated with increased vascular density. Human Pathology 200132 10-17.

7 Soh EY, Duh QY, Sobhi SA, Young DM, Epstein HD, Wong MG, Garcia YK, Min YD, Grossman RF, Siperstein AE \& Clark OH. Vascular endothelial growth factor expression is higher in differentiated thyroid cancer than in normal or benign thyroid. Journal of Clinical Endocrinology and Metabolism 199782 3741-3747.

8 Kilicarslan AB, Ogus M, Arici C, Pestereli HE, Cakir M \& Karpuzoglu G. Clinical importance of vascular endothelial growth factor (VEGF) for papillary thyroid carcinomas. Acta Pathologica, Microbiologica et Immunologica Scandinava 2003111 439-443.

9 Lennard CM, Patel A, Wilson J, Reinhardt B, Tuman C, Fenton C, Blair E, Francis GL \& Tuttle RM. Intensity of vascular endothelial growth factor expression is assiociated with increased risk of recurrence and decreased disease-free survival in papillary thyroid cancer. Surgery 2001129 552-558.

10 Klein M, Vignaud JM, Hennequin V, Toussaint B, Bresler L, Plenat F, Leclere J, Duprez A \& Weryha G. Increased expression of the vascular endothelial growth factor is a pejorative prognosis marker in papillary thyroid carcinoma. Journal of Clinical Endocrinology and Metabolism 200186 656-658.

11 Fenton C, Patel A, Dinauer C, Robie DK, Tuttle RM \& Francis GL. The expression of the vascular endothelial growth factor and the type 1 vascular endothelial growth factor receptor correlate with the size of papillary thyroid cancer in children and young adults. Thyroid 200010 349-357.
12 Lewy-Trenda I \& Wierzchniewska-Lawska A. Expression of vascular endothelial growth factor (VEGF) in thyroid tumors. Polish Journal of Pathology 200253 129-132.

13 Klein M, Picard E, Vignaud JM, Marie B, Bresler L, Toussaint B, Weryha G, Duprez A \& Leclere J. Vascular endothelial growth factor gene and protein: strong expression in thyroiditis and thyroid carcinoma. Journal of Endocrinology 1999161 41-49.

14 Siironen P, Louhimo J, Nordling S, Ristimaki A, Maenpaa H, Haapiainen R \& Haglund C. Prognostic factors in papillary thyroid cancer: an evaluation of 601 consecutive patients. Tumour Biology 200526 57-64.

15 Tuttle RM, Fleisher M, Francis GL \& Robbins RJ. Serum vascular endothelial growth factor levels are elevated in metastatic differentiated thyroid cancer but not increased by short-term TSH stimulation. Journal of Clinical Endocrinology and Metabolism 200287 1737-1742.

16 Sorvillo F, Mazziotti G, Carbone A, Piscopo M, Rotondi M, Cioffi M, Musto P, Biondi B, Iorio S, Amato G \& Carella C. Recombinant human thyrotropin reduces serum vascular endothelial growth factor levels in patients monitored for thyroid carcinoma even in the absence of thyroid tissue. Journal of Clinical Endocrinology and Metabolism 200388 4818-4822.

17 Soh EY, Sobhi SA, Wong MG, Meng YG, Siperstein AE, Clark OH \& Duh QY. Thyroid-stimulating hormone promotes the secretion of vascular endothelial growth factor in thyroid cancer cell lines. Surgery 1996120 944-947.

18 Viglietto G, Romano A, Manzo G, Chiappetta G, Paoletti I, Califano D, Galati MG, Mauriello V, Bruni P, Lago CT, Fusco A \& Persico MG. Upregulation of the angiogenic factors PIGF, VEGF and their receptors (Flt-1, Flk-1/KDR) by TSH in cultured thyrocytes and in the thyroid gland thiouracyl-fed rats suggests a TSH-dependent paracrine mechanism for goiter hypervascularization. Oncogene 199715 2687-2698.

19 Yamada E, Yamazaki K, Takano K, Obara T \& Sato K. Iodine inhibits vascular endothelial growth factor expression in cultured human thyroid follicles: a microarray research for effects of thyrotropin and iodine on angiogenesis factors. Thyroid 200616 545-554.

20 Izumiya Y, Shiojima I, Sato K, Sawyer DB, Colucci WS \& Walsh K. Vascular endothelial growth factor blockade promotes the transition from compensatory cardiac hypertrophy to failure in response to pressure overload. Hypertension 200647 887-893.

21 Greaves JP, Gutekunst R \& Dunn JT. Training course in ultrasonography for endemic goiter. International Council for Control of Iodine Deficiency Disorders 19917 (1).

22 Huang SM, Lee JC, Wu TJ \& Chow NH. Clinical relevance of vascular endothelial growth factor for thyroid neoplasms. World Journal of Surgery 200125 302-306.

23 Bunone G, Vigneri P, Mariani L, Buto S, Collini P, Pilotti S, Pierotti MA \& Bongarzone I. Expression of angiogenesis stimulators and inhibitors in human thyroid tumors and correlation with clinical pathological features. American Journal of Pathology 1999155 1967-1976.

24 Fellmer PT, Sato K, Tanaka R, Okamoto T, Kato Y, Kobayashi M, Shibuya M \& Obara T. Vascular endothelial growth factor-C gene expression in papillary and follicular thyroid carcinomas. Surgery 1999126 1056-1061.

25 Jiang HG, Gao M, Tang WP, Li FH \& Cai QZ. Expression and significance of VEGF, VEGF-C, and VEGF-D in papillary thyroid carcinoma. Ai Zheng 200524 1136-1139.

26 Ferrara N. Vascular endothelial growth factor: basic science and clinical progress. Endocrine Reviews 200425 581-611.

27 Hinoda Y, Sasaki S, Ishida T \& Imai K. Monoclonal antibodies as effective therapeutic agents for solid tumors. Cancer Science 200495 621-625.

28 Bauer AJ, Patel A, Terrell R, Doniparthi K, Saji M, Ringel M, Tuttle RM \& Francis GL. Systemic administration of vascular endothelial growth factor monoclonal antibody reduces growth of papillary thyroid carcinoma in nude mouse model. Annals of Clinical and Laboratory Science 200333 192-199. 
29 Younes MN, Yazici YD, Kim S, Jasser SA, El-Naggar AK \& Myers JN. Dual epidermal growth factor and vascular endothelial growth factor receptor inhibition with NVP-AEE788 for the treatment of aggressive follicular thyroid cancer. Clinical Cancer Research 200612 3425-3434.

30 Sorisky A, Bell A \& Gagnon A. TSH receptor in adipose cells. Hormone and Metabolic Research 200032 468-474.

31 Miyagi E, Katoh R, Li X, Lu S, Suzuki K, Maeda S, Shibuya M \& Kawaoi A. Thyroid stimulating hormone downregulates vascular endothelial growth factor expression in FRLT-5 cells. Thyroid 2001 11 539-543.

32 Suzuki K, Mori A, Lavaroni S, Ullianich L, Miyagy E \& Sato J. Thyroglobulin regulates follicular function and heterogeneity by suppressing thyroid-specific gene expression. Biochimie $1999 \mathbf{8 1}$ 329-340.

33 Sato K, Yamazaki K, Shizume K, Kanaji Y, Obara T \& Ohsumi K. Stimulation by thyroid-stimulating hormone and Grave's immunoglobulin G of vascular endothelial growth factor mRNA expression in human thyroid follicles in vitro and flt mRNA expression in the rat thyroid in vivo. Journal of Clinical Investigation $1995961295-1302$.
34 Hoffmann S, Hofbauer LC, Scharrenbach V, Wunderlich A, Hassan I, Lingelbach S \& Zielke A. Thyrotropin (TSH)-induced production of vascular endothelial growth factor in thyroid cancer cells in vitro: evaluation of TSH signal transduction and of angiogenesis-stimulating growth factors. Journal of Clinical Endocrinology and Metabolism 200489 6139-6145.

35 Gerard AC, Xhenseval V, Colin IM, Many MC \& Denef JF. Evidence for coordinated changes between vascular endothelial growth factor and nitric oxide synthase III immunoreactivity, the functional status of the thyroid follicles, and the microvascular bed during chronic stimulation by low iodine and propylthiouracyl in old mice. European Journal of Endocrinology 2000142 651-666.

Received 16 April 2007

Accepted 24 July 2007 